\title{
Are IQ tests enough to measure intelligence in the blind? Brief review of available and potential methods to estimate intelligence in the blind
}

\begin{abstract}
Measuring intelligence in the blind population is a very challenging task. The Wechsler Adult Intelligence Scale, one of the most popular IQ tests, is not suitable due to its reliance on visual stimuli. However, one can observe that neuroscientists have started to look for neural correlates of intelligence, for example by measuring the accuracy of performance in a popular n-back task while subjects undergo fMRI scans. It has been shown that the so-called general intelligence strongly correlates with the memory system in sighted people. Since working memory can also be tested independently of a given sensory input, it can prove to be an excellent tool to measure the working memory capacity, which can serve as a neural correlate of intelligence in the blind.
\end{abstract}

Keywords: IQ tests, blind, partially sighted, intelligence, n-back

\section{Introduction}

Intelligence "... is not something which can be expressed by one single factor alone, say 'g', whether you define it in its most general terms as mental energy, the ability to educe relations or merely as the intellective factor. Intelligence is all this and yet something more" [Wechsler, 1994, p. 11]. Intelligence, often defined as an ability to perceive, analyze and adapt to environmental changes, although examined by teams of researchers for decades, still remains challenging to measure. Estimating this feature in sighted people is definitely not an easy task. An even greater challenge is to measure intelligence in the blind. "How do blind people get their IQs tested? Is it even possible?" These frequently asked questions still have not been answered fully. ${ }^{1}$

1 See Internet Forum: https://www.quora.com/How-do-blind-people-get-their-IQs-tested-Is-iteven-possible 


\subsection{Intelligence tests for sighted individuals}

The Wechsler Adult Intelligence Scale (WAIS) is one of the most popular IQ tests. It consists of two scales: verbal and nonverbal [Hornowska, 2004]. While the early version allowed measuring only verbal and nonverbal intelligence, the current one (WAIS-IV) includes ten subtests that examine many aspects of human intellect, including memory. It was released in 2008 and consists of ten core subtests comprising the Full Scale IQ and five supplementary subtests. In the new WAIS-IV, the verbal and performance subscales were removed and replaced by index scores. Next, the General Ability Index (GAI) was included. It consists of the Similarities, Vocabulary and Information subtests from the Verbal Comprehension Index and the Block Design, Matrix Reasoning and Visual Puzzles subtests from the Perceptual Reasoning Index. In clinical environment the GAI can be useful because it measures cognitive abilities that are less sensitive to processing and working memory impairments. It is one of the most popular methods used to measure intelligence in the world [Hornowska, 2004]. The current Polish adaptation of this test, for sighted individuals, called WAIS-R (PL) $(\mathrm{R}=$ revised) consists of 11 tests examining the level of development of various cognitive abilities.

Moreover, the verbal scale of WAIS serves as a validity reference for other tests attempting to measure intelligence in the blind population [Atkins, 2011; see Table $1 \mathrm{a}-\mathrm{c}]$. The setup of the scale makes it possible to be used without any major adjustments with the blind population. According to Miller and Skillman [2003, after Atkins, 2011, p. 7], WAIS is widely used with blind and partially sighted children because of its "flexibility, familiarity, availability, favorable psychometrics and cost effectiveness." While it is clear that the nonverbal scale is not suitable for the blind, the question whether the verbal scale is enough to measure intelligence in such a population remains unanswered. To meet the challenge posed by the lack of well-established tools estimating the level of intelligence in the blind, numerous intelligence tests aimed specifically at this group have been developed. Here we aim to review the most widely-used intelligence tests for the blind.

\subsection{Current psychometric intelligence tests for blind individuals}

Despite the lack of one of the crucial senses - sight - blind people not only lead a normal life but even climb mountain peaks. ${ }^{2}$ Although in intelligence tests they obtain scores similar to sighted individuals [Vander Kolk, 1982], their cognitive development differs. Getting to know the surrounding world, blind children use their 'imaginations' [Kucharczyk, 2015], i.e. forms of mental representations that base on perceptual processes and are unstable [Nęcka, Orzechowski \& Szymura, 2006], fragmentary, schematic, and characterized by verbalism. Moreover, objects relating to spatial imaginations in this population develop later [Kucharczyk, 2015]. However, several experiments showed better performance in short memory tasks in the group of blind people [Röder \& Rösler, 2003] compared to sighted individuals. Moreover,

2 See e.g.: https://www.tvn24.pl/wiadomosci-z-kraju,3/niewidomy-alpinista-zdobywa-koroneeuropy-nie-widze-przeszkod,582856.html. 
neuroimaging experiments showed that the visual cortex in congenitally blind subjects becomes activated by reading tactile Braille [Sadato et al., 1996; Burton et al., 2002; Reich et al., 2011], and by other higher cognitive tasks such as memory processing (e.g. recalling previously learned words [Amedi et al., 2003]), language processing [Röder et al., 2002] or touching meaningless textures [Amedi et al., 2001]. Nevertheless, the congenitally and late blind seem to significantly differ in some tasks (e.g. haptic processing [Postma et al., 2007]) and in activation of the visual cortex triggered by e.g. processing words [Büchel et al., 1998].

Despite all the differences, many researchers aiming to create an intelligence test for blind (overall for both congenitally and late blind) or visually impaired individuals adapted the already well-established tests for sighted individuals. For example, the Cognitive Test for the Blind developed by Nelson, Dial and Joyce [2002] is based on the WAIS verbal scale. Although the test is based on WAIS, when researchers correlated the results obtained from the WAIS nonverbal scale and the results from the above-mentioned test, the correlation was rather low. Another test is the Perkins-Binet Tests of Intelligence for the Blind. Although the authors [Teare \& Thompson, 1982] reported high correlations between both forms of the Perkins-Binet and the Wechsler scales, they also demonstrated substantial differences in the standard deviations for the particular tests. This suggests that although adapting certain scales from the IQ tests for the sighted is possible in the case of the blind, it certainly is not without its drawbacks. Tables $1 \mathrm{a}, 1 \mathrm{~b}$, and $1 \mathrm{c}$ show an overview of the current tests used to measure intelligence in the blind.

Table 1a

\begin{tabular}{|c|c|c|}
\hline \multicolumn{3}{|c|}{$\begin{array}{l}\text { Group of Wechsler's Intelligence Tests adapted for the blind and individuals with visual } \\
\text { impairments }\end{array}$} \\
\hline Test & Application & Adaptation \\
\hline $\begin{array}{l}\text { Wechsler Adult } \\
\text { Intelligence Scale, } \\
\mathbf{3}^{\text {rd }} \text { Edition (WAIS- } \\
\text {-III) } \\
\text { [Wechsler, 1997] }\end{array}$ & $\begin{array}{l}\text { Uses only the Verbal Scale [Atkins, } \\
2011 \text { ]. } \\
\text { The Verbal Scale has seven } \\
\text { subtests: Vocabulary, Similarities, } \\
\text { Arithmetic, Digit Span, Information, } \\
\text { Comprehension, Letter-Number } \\
\text { Sequencing [Hornowska, 2004]. } \\
\text { Measures: concentration, mental } \\
\text { manipulation, auditory processing, } \\
\text { encoding, working memory, } \\
\text { semantic knowledge, abstract verbal } \\
\text { reasoning, verbal comprehension } \\
\text { and expression [Hornowska, 2004]. }\end{array}$ & $\begin{array}{l}\text { The tactile and psychometric tests } \\
\text { for the blind have a valid accuracy in } \\
\text { relation to this test, e.g.: } \\
\text { The Perkins-Binet Tests of } \\
\text { Intelligence for the Blind [Atkins, } \\
\text { 2011], Adaptive Behavior } \\
\text { Assessment System, 2 } 2^{\text {nd }} \text { Edition } \\
\text { (ABAS-II) [Rust \& Wallace, 2004], } \\
\text { Ohwaki-Kohs Block Design Test } \\
\text { [Brand, Pieterse \& Frost, 1986], 3-D } \\
\text { Haptic Matrix Test of Nonverbal } \\
\text { Reasoning [Miller et al., 2007] etc. } \\
\text { Studies comparing blind and sighted } \\
\text { individuals show non-intergroup } \\
\text { differences [Vander Kolk, 1982]. } \\
\text { Does not diagnose nonverbal } \\
\text { reasoning [Cassar \& Lucchese, } \\
\text { 2016]. }\end{array}$ \\
\hline
\end{tabular}




\begin{tabular}{|c|c|c|}
\hline & & $\begin{array}{l}\text { Developed for people without visual } \\
\text { impairments (from } 16 \text { to } 89 \text { years } \\
\text { old) [Hornowska, 2004]. } \\
\text { Only the Verbal Scale has been } \\
\text { adapted for people with visual } \\
\text { impairments and standardization } \\
\text { has never been conducted in the } \\
\text { blind population; it is suggested } \\
\text { that no procedural or structural } \\
\text { adaptation is necessary [Hill-Briggs, } \\
\text { Dial, Morere \& Joyce, 2007]. } \\
\text { It is not possible to calculate IQ } \\
\text { because the test consists of the } \\
\text { Verbal Scale and the Performance } \\
\text { Scale only [Hornowska, 2004]. }\end{array}$ \\
\hline $\begin{array}{l}\text { Wechsler } \\
\text { Abbreviated Scale } \\
\text { of Intelligence } \\
\text { (WASI) } \\
\text { [Wechsler, 1999] }\end{array}$ & $\begin{array}{l}\text { Brief measure of general intelligence } \\
\text { [Canivez, Konold, Collins \& Wilson, } \\
\text { 2009]. } \\
\text { Full battery consists of four subtests: } \\
\text { Vocabulary, Similarities (the } \\
\text { subtests combine to measure verbal- } \\
\text { crystallized abilities), Block Design } \\
\text { and Matrix Reasoning [Canivez et } \\
\text { al., 2009]. }\end{array}$ & $\begin{array}{l}\text { Developed for people without visual } \\
\text { impairments (from } 6 \text { to } 89 \text { years old) } \\
\text { [Canivez et al., 2009]. }\end{array}$ \\
\hline $\begin{array}{l}\text { Wechsler } \\
\text { Intelligence Scale } \\
\text { for Children, } 3^{\text {rd }} \\
\text { Edition Integrated } \\
\text { (WISC-III) } \\
\text { [Wechsler, 1991] }\end{array}$ & $\begin{array}{l}\text { Uses only the Verbal Scale [Spencer, } \\
\text { 1996]. } \\
\text { Measures verbal intellectual } \\
\text { development [Spencer, 1996]. }\end{array}$ & $\begin{array}{l}\text { This test was historically one of } \\
\text { the most widely used instruments } \\
\text { to measure the verbal intellectual } \\
\text { development of blind children } \\
\text { [Spencer, 1996]. } \\
\text { Developed for children without } \\
\text { visual impairments (from } 6 \text { to } 16 \\
\text { years old) [Spencer, 1996]. } \\
\text { Only the Verbal Scale has been } \\
\text { adapted for people with visual } \\
\text { impairments and standardization } \\
\text { has never been conducted in the } \\
\text { blind population; it is suggested } \\
\text { that no procedural or structural } \\
\text { adaptation is necessary [Hill-Briggs } \\
\text { et al., 2007]. }\end{array}$ \\
\hline
\end{tabular}

Source: [Atkins, 2011; Brand et al., 1986; Canivez et al., 2009; Cassar \& Lucchese, 2016; Hill-Briggs et al., 2007; Hornowska, 2004; Miller et al., 2007; Spencer, 1996; Rust \& Wallace, 2004; Vander Kolk, 1982]. 
Table 1b

\begin{tabular}{|c|c|c|}
\hline \multicolumn{3}{|c|}{ Psychometric tests developed for the blind and individuals with visual impairments } \\
\hline Test & Application & Adaptation \\
\hline $\begin{array}{l}\text { The Interim Hayes- } \\
\text {-Binet Intelligence } \\
\text { Scale } \\
\text { Developed at the } \\
\text { Perkins Institution } \\
\text { in } 1942 .\end{array}$ & $\begin{array}{l}\text { Created with the use of items from } \\
\text { the Stanford-Binet Intelligence Scale, } \\
\text { in which the participants are not } \\
\text { required to use vision [Ashcroft, } \\
\text { 1959]. } \\
\text { Measures academic achievements } \\
\text { [Atkins, 2011]. }\end{array}$ & $\begin{array}{l}\text { Published in } 1942 \text { and } \\
\text { standardized for the United States } \\
\text { [Atkins, 2011]. }\end{array}$ \\
\hline $\begin{array}{l}\text { Williams } \\
\text { Intelligence Test for } \\
\text { VI Children } \\
\text { [Williams, 1956] }\end{array}$ & $\begin{array}{l}\text { Measures verbal intelligence [Atkins, } \\
\text { 2011; Tobin \& Hill, 2011]. } \\
\text { It has one intelligence score [Atkins, } \\
\text { 2011; Tobin \& Hill, 2011]. }\end{array}$ & $\begin{array}{l}\text { Developed for blind and partially } \\
\text { sighted children (from } 4 \text { to } 16 \\
\text { years old) [Williams, 1956; Tobin } \\
\text { \& Hill, 2011]. } \\
\text { Standardized in the UK [Atkins, } \\
\text { 2011]. }\end{array}$ \\
\hline $\begin{array}{l}\text { The Blind Learning } \\
\text { Aptitude Test } \\
\text { (BLAT) } \\
\text { [Newland, 1969] }\end{array}$ & $\begin{array}{l}\text { Raised line symbols similar to Braille } \\
\text { characters [Atkins, 2011; Newland, } \\
\text { 1969]. } \\
\text { Task: Differentiate between } \\
\text { symbols and make deductions } \\
\text { [Newland,1969]. } \\
\text { Measures: arythmetic reasoning, } \\
\text { memorization [Newland, 1969]. }\end{array}$ & $\begin{array}{l}\text { Tasks used are an adaptation } \\
\text { of items from the Culture Fair } \\
\text { Intelligence Test and the Raven } \\
\text { Progressive Matrices [Atkins, } \\
2011 \text { ]. } \\
\text { Used for testing blind children } \\
\text { (from } 6 \text { to } 16 \text { years old) in } \\
\text { England, Wales, India and the } \\
\text { United States [Mason \& Shukla, } \\
\text { 1992]. } \\
\text { Period of application: USA (1952- } \\
\text { 1969); India (1986-1991); England } \\
\text { and Wales (1987-1989) [Mason } \\
\text { \& Shukla, 1992; Shukla, 1990]. } \\
\text { Correlated with WISC-R Verbal } \\
\text { Scale Braille reading speed [Atkins, } \\
\text { 2011; Newland, 1990]. }\end{array}$ \\
\hline $\begin{array}{l}\text { The Perkins-Binet } \\
\text { Tests of Intelligence } \\
\text { for the Blind } \\
\text { [Davis, 1980] }\end{array}$ & $\begin{array}{l}\text { Measures the verbal and } \\
\text { performance function [Ward } \\
\text { \& Genshaft, 1983]. }\end{array}$ & $\begin{array}{l}\text { Developed for the blind and } \\
\text { partially sighted people (from } 3 \text { to } \\
18 \text { years old) [Ward \& Genshaft, } \\
1983 \text { ]. } \\
\text { Poor correlation with WAIS } \\
\text { [Atkins, 2011]. }\end{array}$ \\
\hline
\end{tabular}




\begin{tabular}{|c|c|c|}
\hline $\begin{array}{l}\text { Developmental } \\
\text { Activities Screening } \\
\text { Inventory, } 2^{\text {nd }} \\
\text { Edition (DASI-II) } \\
\text { [Fewell \& Langley, } \\
\text { 1984] }\end{array}$ & $\begin{array}{l}\text { Measures fifteen primary functions: } \\
\text { sensory intactness, memory, } \\
\text { means-end relationships, causality, } \\
\text { reasoning) [Acar, Hansen, Dolata } \\
\text { \& Chen, 2014]. }\end{array}$ & $\begin{array}{l}\text { Developed for children without } \\
\text { disabilities and children with } \\
\text { visual impairments (from birth to } \\
60 \text { months) [Acar et al., 2014]. } \\
\text { Adapted for visually impaired } \\
\text { children (tactile version) [Bishop, } \\
\text { 1991]. }\end{array}$ \\
\hline $\begin{array}{l}\text { Cognitive Test for } \\
\text { the Blind (CTB) } \\
\text { [Dial et al., 1990] }\end{array}$ & $\begin{array}{l}\text { Measures: cognitive functions } \\
\text { including: abstract reading, auditory } \\
\text { language functions, memory, spatial } \\
\text { sections [Atkins, 2011]. } \\
\text { Consists of five Verbal Scales and } \\
\text { five nonvisual Performance Scales } \\
\text { [Nelson et al., 2002]. }\end{array}$ & $\begin{array}{l}\text { Correlated with WAIS [Nelson } \\
\text { et al., 2002]. } \\
\text { Developed for children without } \\
\text { visual impairments (over } 14 \text { years } \\
\text { old) [Nelson et al., 2002]. }\end{array}$ \\
\hline $\begin{array}{l}\text { The Intelligence } \\
\text { Test for Visually } \\
\text { Impaired Children } \\
\text { [Dekker, 1993] }\end{array}$ & $\begin{array}{l}\text { Consists of verbal and tactile } \\
\text { subtests based on WISC [Dekker, } \\
\text { 1993]. } \\
\text { Measures nonverbal intelligence } \\
\text { [Dekker, 1993]. }\end{array}$ & $\begin{array}{l}\text { Developed for blind and partially } \\
\text { sighted children (from } 6 \text { to } 15 \\
\text { years old) [Dekker, 1993]. } \\
\text { Published in Dutch, German and } \\
\text { English [Atkins, 2011]. } \\
\text { Standardized in Belgium and in the } \\
\text { Netherlands [Atkins, 2011]. }\end{array}$ \\
\hline $\begin{array}{l}\text { Iowa Tests of Basic } \\
\text { Skills (ITBS) } \\
\text { [Hoover, Dunbar } \\
\text { \& Frisbie, 1993] }\end{array}$ & $\begin{array}{l}\text { Measures growth in the functional } \\
\text { skills, e.g. listening, vocabulary, } \\
\text { reading, study, mathematic, analysis, } \\
\text { etc. [Hoover et. al., 2003]. } \\
\text { It has seventeen scores: Vocabulary, } \\
\text { Reading Comprehension, } \\
\text { Language (Spelling, Capitalization, } \\
\text { Punctuation, Usage and Expression, } \\
\text { and Total), Work Study (Visual } \\
\text { Materials, Reference Materials, and } \\
\text { Total), Mathematics (Concepts, } \\
\text { Problem Solving, Computation, and } \\
\text { Total), Complete Composite, Social } \\
\text { Studies, and Science [Hoover et al., } \\
\text { 2003]. }\end{array}$ & $\begin{array}{l}\text { Developed for blind and partially } \\
\text { sighted children (from } 8 \text { to } 14 \\
\text { years old) [Hoover et al., 2003]. }\end{array}$ \\
\hline
\end{tabular}




\begin{tabular}{|c|c|c|}
\hline $\begin{array}{l}\text { Brigance Life Skills } \\
\text { Inventory (LSI) } \\
\text { [Brigance, 1994] }\end{array}$ & $\begin{array}{l}\text { Measures an individual's functioning } \\
\text { within daily life situations [Brigance, } \\
\text { 1994]. } \\
\text { Consists of ten tests: Speaking and } \\
\text { Listening Skills, Functional Writing } \\
\text { Skills, Words on Common Signs and } \\
\text { Warning Labels, Telephone Skills, } \\
\text { Money and Finance, Food, Clothing, } \\
\text { Health, Travel and Transportation } \\
\text { [Brigance, 1994; Bradley-Johnson, } \\
\text { 1997]. } \\
\text { Areas of estimation include: } \\
\text { speaking, listening, writing, money } \\
\text { and financial skills, knowledge of } \\
\text { food and health [Bradley-Johnson, } \\
\text { 1997]. }\end{array}$ & $\begin{array}{l}\text { Developed for children without } \\
\text { visual impairments (over } 13 \text { years } \\
\text { old) [Brigance, 1994]. } \\
\text { Questionnaires are completed by } \\
\text { an observer [Brigance, 1994]. }\end{array}$ \\
\hline $\begin{array}{l}\text { Adaptive Behavior } \\
\text { Assessment System, } \\
2^{\text {nd }} \text { Edition (ABAS-II) } \\
\text { [Harrison \& Oakland, } \\
\text { 2003] }\end{array}$ & $\begin{array}{l}\text { Incudes ten different skill scores } \\
\text { (Communication, Community } \\
\text { Use, Functional Academics, Health } \\
\text { and Safety, Home or School Living, } \\
\text { Leisure, Safe-Care, Self-Direction, } \\
\text { Social and Work); uses 193-241 } \\
\text { items [Rust \& Wallace, 2004]. } \\
\text { Questionnaire is completed by } \\
\text { parents, teachers or caregivers [Rust } \\
\text { \& Wallace, 2004]. }\end{array}$ & $\begin{array}{l}\text { Developed for children (0-21 years } \\
\text { old) and adults (16-89 years old) } \\
\text { [Harrison \& Oakland, 2003]. } \\
\text { Different studies revealed } \\
\text { correlation in the } 0.40 \text { s and in } \\
\text { the } 0.50 \text { s between ABAS-II and } \\
\text { other measures of intelligence } \\
\text { (e.g. WAIS-III, WISC-IV) [Rust } \\
\text { \& Wallace, 2004]. } \\
\text { Standardization done on certain } \\
\text { groups of people (with the } \\
\text { same dysfunction, e.g. visual } \\
\text { impairments, ADHD, etc.) [Rust } \\
\text { \& Wallace, 2004]. }\end{array}$ \\
\hline $\begin{array}{l}\text { Woodcock- } \\
\text { Johnson III Tests } \\
\text { of Achievement } \\
\text {-Braille Edition } \\
\text { (WJ-III) } \\
\text { [Woodcock } \\
\text { \& Johnson, 2005] }\end{array}$ & $\begin{array}{l}\text { Measures: cognitive abilities, } \\
\text { scholastic aptitudes and } \\
\text { achievements [Abu-Hamour, } \\
\text { Hmouz, Mattar \& Muhaidat, 2012]. } \\
\text { Based on Cattell-Horn-Carroll } \\
\text { Theory [Abu-Hamour et al., 2012]. } \\
\text { Test includes tests of: comprehension } \\
\text { knowledge, vocabulary, visual } \\
\text { auditory learning, spatial relations, } \\
\text { sound blending, concept formation, } \\
\text { visual matching, numbers reversed, } \\
\text { incomplete words, auditory working } \\
\text { memory, visual auditory learning } \\
\text { delayed [Wechsler et al., 2010]. }\end{array}$ & $\begin{array}{l}\text { Developed for blind and partially } \\
\text { sighted people [Abu-Hamour et al., } \\
\text { 2012]. } \\
\text { Standardized academic } \\
\text { achievement battery has been } \\
\text { specifically adapted for Braille } \\
\text { readers [Abu-Hamour et al., 2012]. }\end{array}$ \\
\hline
\end{tabular}

Source: [Abu-Hamour et al., 2012; Acar et al., 2014; Atkins, 2011; Ashcroft, 1959; Bishop, 1991; Bradley-Johnson, 1997; Brigance, 1994; Dekker, 1993; Harrison \& Oakland, 2003; Hoover et al., 2003; Mason \& Shukla, 1992; Nelson et al., 2002; Newland, 1969; Newland, 1990; Rust \& Wallace, 2004; Shukla, 1990; Tobin \& Hill, 2011; Ward \& Genshaft, 1983; Wechsler et al., 2010; Williams, 1956]. 
Table 1c

\begin{tabular}{|c|c|c|}
\hline \multicolumn{3}{|c|}{ Haptic tests for measuring intelligence in the blind and individuals with visual impairments } \\
\hline Test & Application & Adaptation \\
\hline $\begin{array}{l}\text { Ohwaki-Kohs } \\
\text { Block Design Test } \\
\text { [Ohwaki, Tanno, } \\
\text { Ohwaki, Hariu, } \\
\text { Hasasake \& Miyake, } \\
\text { 1960] }\end{array}$ & $\begin{array}{l}\text { Made of 3-D textured blocks } \\
\text { [Mazella, Albaret \& Picard, 2014]. } \\
\text { Task: Adjust blocks to the model } \\
\text { [Mazella et al., 2014]. } \\
\text { Measures nonverbal intelligence } \\
\text { [Mazella et al., 2014]. } \\
\text { Based on Kohs Block Design Test } \\
\text { [Brand et al., 1986]. }\end{array}$ & $\begin{array}{l}\text { Developed for blind and partially } \\
\text { sighted people (from } 6 \text { to } 21 \text { years } \\
\text { old) [Mazella et al., 2014]. } \\
\text { Correlated with WAIS [Brand et al., } \\
\text { 1986]. } \\
\text { Used in English and Japanese } \\
\text { [Mazella et al., 2014]. }\end{array}$ \\
\hline $\begin{array}{l}\text { The D48 Test } \\
\text { [Gough \& Domino, } \\
\text { 1963] }\end{array}$ & $\begin{array}{l}\text { Consists of a series of haptic tests } \\
\text { [Gough \& Domino, 1963]. } \\
\text { Task: Find missing tactile dominoes } \\
\text { [Gough \& Domino, 1963]. } \\
\text { Uses 3-D objects [Mazella et al., } \\
\text { 2014]. } \\
\text { Measures nonverbal intelligence } \\
\text { [Gough \& Domino, 1963]. }\end{array}$ & $\begin{array}{l}\text { Developed for blind and partially } \\
\text { sighted adults (over } 18 \text { years old) } \\
\text { [Mazella et al., 2014]. } \\
\text { Correlated with WAIS [Mazella } \\
\text { et al., 2014]. } \\
\text { Very difficult and stressful for the } \\
\text { participants [Mazella et al., 2014]. } \\
\text { Used in English in the USA [Gough } \\
\text { \& Domino, 1963]. }\end{array}$ \\
\hline $\begin{array}{l}\text { Manual Haptic } \\
\text { Intelligence Scale } \\
\text { for Adult Blind } \\
\text { [Schurrager } \\
\text { \& Schurrager, 1964] }\end{array}$ & $\begin{array}{l}\text { Consists of six subtests: digit } \\
\text { symbol, object assembly, block } \\
\text { design, object completion, pattern } \\
\text { board, bead arithmetic [Mazella } \\
\text { et al., 2014]. } \\
\text { Uses 3-D objects, 3-D shapes, 2-D } \\
\text { raised shapes [Mazella et al., 2014]. } \\
\text { Measures nonverbal intelligence } \\
\text { [Mazella et al., 2014]. }\end{array}$ & $\begin{array}{l}\text { Developed for blind and partially } \\
\text { sighted people (from } 16 \text { to } 64 \text { years } \\
\text { old) [Mazella et al., 2014]. } \\
\text { Correlated with WAIS [Mazella } \\
\text { et al., 2014]. } \\
\text { Used in English in the USA } \\
\text { [Mazella et al., 2014]. }\end{array}$ \\
\hline $\begin{array}{l}\text { The Tactual } \\
\text { Progressive } \\
\text { Matrices } \\
\text { [Anderson \& Beltz, } \\
1964 \text { ] }\end{array}$ & $\begin{array}{l}\text { Consists of a series of haptic tests. } \\
\text { Based on the Raven Standard } \\
\text { Progressive Matrices [Rich, 1963; } \\
\text { Rich \& Anderson, 1965]. } \\
\text { Constructed of balsa wood and } \\
\text { sandpaper [Rich, 1963; Rich } \\
\text { \& Anderson, 1965]. } \\
\text { To reproduce the test items from } \\
\text { the visual Raven Test it uses 2-D } \\
\text { raised shapes [Rich, 1963; Rich } \\
\text { \& Anderson, 1965]. } \\
\text { Measures nonverbal intelligence } \\
\text { [Rich, 1963; Rich \& Anderson, } \\
\text { 1965]. }\end{array}$ & $\begin{array}{l}\text { Developed for blind and partially } \\
\text { sighted people (from } 16 \text { to } 64 \text { years } \\
\text { old) [Rich, 1963; Rich \& Anderson, } \\
\text { 1965]. } \\
\text { Correlated with WAIS [Rich, 1963; } \\
\text { Rich \& Anderson, 1965]. } \\
\text { Discontinued due to very high costs } \\
\text { [Mazella et al., 2014]. }\end{array}$ \\
\hline
\end{tabular}




\begin{tabular}{|c|c|c|}
\hline $\begin{array}{l}\text { Stanford-Ohwaki- } \\
\text {-Kohs Tactile Block } \\
\text { Design Test } \\
\text { [Suinn, Dauterman } \\
\text { \& Shapiro, 1966] }\end{array}$ & $\begin{array}{l}\text { Made of 3-D textured blocks [Suinn } \\
\text { et al., 1966]. } \\
\text { Task: Adjust blocks to the model } \\
\text { [Suinn et al., 1966]. } \\
\text { Measures nonverbal intelligence } \\
\text { [Suinn et al., 1966]. } \\
\text { Based on Ohwaki-Kohs Block } \\
\text { Design Test and on Kohns Block } \\
\text { Design Test [Dauterman, 1965; } \\
\text { Suinn et al., 1966]. }\end{array}$ & $\begin{array}{l}\text { Developed for blind and partially } \\
\text { sighted people [Dauterman, 1965; } \\
\text { Suinn et al., 1966]. } \\
\text { Correlated with WAIS [Dauterman, } \\
\text { 1965; Suinn et al., 1966]. } \\
\text { Used in English in the USA } \\
\text { [Mazella et al., 2014]. }\end{array}$ \\
\hline $\begin{array}{l}\text { Vithoba Paknikar } \\
\text { Performance Test } \\
\text { for the Blind } \\
\text { [Paknikar, 1981] }\end{array}$ & $\begin{array}{l}\text { Uses 3-D objects [Paknikar, 1981]. } \\
\text { Task: Discriminate shapes, textures } \\
\text { and weights [Paknikar, 1981]. } \\
\text { Measures nonverbal intelligence } \\
\text { [Paknikar, 1981]. }\end{array}$ & $\begin{array}{l}\text { Developed for blind and partially } \\
\text { sighted people (from } 8 \text { to } 22 \text { years } \\
\text { old) [Paknikar, 1981]. } \\
\text { Used in Hindi [Paknikar, 1981]. }\end{array}$ \\
\hline $\begin{array}{l}\text { Tactile TONI } \\
\text { [Duncan, Weidel, } \\
\text { Prickett, Vernon } \\
\text { \& Hollingsworth- } \\
\text { Hodges, 1989] }\end{array}$ & $\begin{array}{l}\text { Uses 2-D objects [Duncan et al., } \\
\text { 1989]. } \\
\text { Task: Find appropriate figures to } \\
\text { complete the series [Duncan et al., } \\
\text { 1989]. } \\
\text { Measures nonverbal intelligence } \\
\text { [Duncan et al., 1989]. }\end{array}$ & $\begin{array}{l}\text { Developed for blind and partially } \\
\text { sighted people (from } 19 \text { to } 50 \text { years } \\
\text { old) [Duncan et al., 1989]. } \\
\text { Correlated with WAIS [Duncan } \\
\text { et al., 1989]. } \\
\text { Used in English in the USA } \\
\text { [Mazella et al., 2014]. }\end{array}$ \\
\hline $\begin{array}{l}\text { Adapted Kohs } \\
\text { Block Design Test } \\
\text { [Reid, 2002] }\end{array}$ & $\begin{array}{l}\text { Made of 3-D textured blocks [Reid, } \\
\text { 2002]. } \\
\text { Task: Adjust blocks to the model } \\
\text { [Reid, 2002]. } \\
\text { Measures non-verbal intelligence } \\
\text { [Reid, 2002]. } \\
\text { Based on Kohns Block Design Test } \\
\text { [Reid, 2002]. }\end{array}$ & $\begin{array}{l}\text { Developed for the blind and } \\
\text { partially sighted people (from } 16 \text { to } \\
64 \text { years old) [Reid, 2002]. } \\
\text { Correlated with WAIS [Reid, 2002]. } \\
\text { Used in English in the UK [Mazella } \\
\text { et al., 2014]. }\end{array}$ \\
\hline $\begin{array}{l}\text { B-101-DV } \\
\text { [Thiebaut, Collin, } \\
\text { Bâton \& Fourtier, } \\
\text { 2002] }\end{array}$ & $\begin{array}{l}\text { Made of 3-D textured blocks } \\
\text { [Mazella et al., 2014]. } \\
\text { Task: Adjust blocks to the model } \\
\text { [Mazella et al., 2014]. } \\
\text { Measures: practical intelligence and } \\
\text { tactile-spatial reasoning [Mazella } \\
\text { et al., 2014]. } \\
\text { Based on Kohs Block Design Test } \\
\text { [Mazella et al., 2014]. }\end{array}$ & $\begin{array}{l}\text { Developed for blind and partially } \\
\text { sighted people (from } 16 \text { to } 59 \text { years } \\
\text { old) [Mazella et al., 2014]. } \\
\text { Used in French [Mazella et al., } \\
\text { 2014]. }\end{array}$ \\
\hline
\end{tabular}




\begin{tabular}{|l|l|l|}
\hline $\begin{array}{l}\text { 3-D Haptic Matrix } \\
\text { Test of Nonverbal } \\
\text { Reasoning } \\
\text { [Miller et al., 2007] }\end{array}$ & $\begin{array}{l}\text { Uses 3-D objects [Miller et al., } \\
\text { 2007]. } \\
\text { Task: Complete the matrix [Miller } \\
\text { et al., 2007]. } \\
\text { Measures nonverbal cognitive } \\
\text { abilities, integration of movement } \\
\text { and vision [Miller et al., 2007]. } \\
\text { Based on the Raven Standard } \\
\text { Progressive Matrices [Miller et al., } \\
\text { 2007]. }\end{array}$ & $\begin{array}{l}\text { Developed for blind and partially } \\
\text { sighted people (from 18 to 79 years } \\
\text { old) [Miller et al., 2007]. } \\
\text { Correlated with CTB and WAIS-III } \\
\text { (verbal score) [Miller et al., 2007]. }\end{array}$ \\
\hline $\begin{array}{l}\text { Haptic-2D } \\
\text { [Mazella, Albaret \& } \\
\text { Picard, 2016] }\end{array}$ & $\begin{array}{l}\text { Consists of 11 haptic tests: } \\
\text { measures scanning skills, tactile } \\
\text { discrimination skills, spatial } \\
\text { comprehension skills, short-term } \\
\text { tactile memory and comprehension } \\
\text { of tactile pictures [Mazella et al., } \\
\text { 2016]. }\end{array}$ & $\begin{array}{l}\text { Developed for blind and partially } \\
\text { sighted people (from 5 to 25 years } \\
\text { old) [Mazella et al., 2016]. } \\
\text { [Mazella et al., 2016]. } \\
\text { Standardized in France [Mazella } \\
\text { et al., 2016]. }\end{array}$ \\
\hline
\end{tabular}

Source: [Brand et al., 1986; Dauterman, 1965; Duncan et al., 1989; Gough \& Domino, 1963; Mazella et al., 2014; Mazella et al., 2016; Miller et al., 2007; Paknikar, 1981; Reid, 2002; Rich, 1963; Rich \& Anderson, 1965; Suinn et al., 1966].

The main issue of using psychometric tests, intended for sighted people, to evaluate IQ in the blind is that the tasks measuring nonverbal intelligence are based on properly functioning vision [Atkins, 2011]. In 1932, in his pioneering study, Livingston investigated intelligence in partially sighted children, using the Revised Stanford Binet Intelligence Scale and then compared the results with those obtained from a group of sighted children [Ashcroft, 1959]. His results did not show any significant differences between the two groups. In the 1950s, the interest in studying intelligence in the blind population increased, which is why in 1942 Hayes created the Interim Hayes-Binet Intelligence Scale. The final effect, however, was not satisfactory [Ashcroft, 1959]. Soon afterwards, the most commonly used intelligence test was created - WAIS - of which the verbal scale was also used to examine the blind [Ashcroft, 1959]. According to Atkins [2011, p. 8] challenges that blind people have to face while resolving an IQ test are, e.g.: "difficulty in accessing text in the size the test is administered in, difficulty in accessing passages to re-read, inaccessible layout, non-verbal reasoning tests often rely on visual interpretation of pictures, skills that are being assessed by psychometric tests are not always the same for blind users as they are for sighted users."

Moreover, on average, blind people read much slower than sighted people, therefore the time given to read a passage in several of those tests is simply inappropriate [Atkins, 2011]. Some suggest that the blind should be given at least twice the amount of time needed to read [Mohammed \& Omar, 2011], while others argue for even three times more time [Wetzel \& Knowlton, 2000].

To address the limitations of the above-mentioned tests, Ohwaki [after Dauterman, 1965; Table 1c] introduced the first haptic test, which consisted of 3-D textured blocks. As all haptic tests, it measures nonverbal intelligence [Mazella et al., 2014]. 
Haptic tests are used to study nonverbal or practical intelligence. They are mainly a final product of an attempt to translate nonverbal tests based on vision (intended for the sighted) into its haptic analog [Mazella et al., 2014], especially since the sense of touch is fundamental for blind children development [Withagen, Vervloed, Janssen, Knoors \& Verhoeven, 2009].

Moreover, according to Mazella [et al., 2014] more than half (54\%) of the haptic tests are analogs of those designed for the sighted, and only $46 \%$ are tests originally designed for the blind. Haptic tests consist of either a single task (e.g. the D48 [Gough \& Domino, 1963, Table 1c]) or multiple subtests (e.g. Haptic-2D [Mazella et al., 2016], but all of them are based on active touch. None of them is based on guided touch [Mazella et al., 2014]. Most of the discussed haptic tests were created in the USA, with the exception of the Performance Test for the Blind [Paknikar, 1981, Table 1c], which was created and standardized in India. To the best of our knowledge, there are no haptic tests for the blind in Poland. The main difficulty is that the blind have a very well-developed sense of touch, therefore the question whether the high performance in those tests is due to sense of touch or to the good performance in the task itself remains unanswered. In summary, all of the above mentioned tests have their advantages and disadvantages, and their results are highly influenced by age, socioeconomic status and age of the sight loss of the person tested. Therefore, it would be highly beneficial to establish one reliable correlate of general intelligence that could provide insights into the cognitive functioning of an individual, both sighted and visually impaired.

\subsection{Working memory and intelligence}

With the development of neuroimaging techniques and other achievements in experimental psychology, scientists started to look for neural correlates of intelligence, for example by measuring the accuracy of performance in a popular n-back task, while undergoing fMRI scans. Working memory refers to a cognitive system characterized by a limited capacity, responsible for maintenance and online manipulation of information that reaches the cognitive system. The study conducted e.g. by Conway, Kane and Engle [2003] showed that general intelligence strongly correlates with the above mentioned memory system (referred to as working memory) in sighted people. Since working memory can be tested independently of a given sensory input (visual, tactile or auditory), it could serve as an excellent additional tool to measure intelligence in the blind by correlating its performance with other tools often used to measure this quality. In the case of blind individuals, many researchers suggested that their cognitive functioning (for example, short term memory) is significantly better compared to sighted subjects, which is contrary to the results obtained in the classic paper-pencil intelligence tests [Röder \& Rösler, 2003; Cohen, Voss, Lepore \& Scherzer, 2010]. Here we discuss the additional tool to measure intelligence in the blind.

The main functions that working memory is responsible for are storage and processing, relational integration and supervision of information [Oberauer, Süß, Wilhelm \& Wittmann, 2008]. The most popular paradigm for exploring working memory is the n-back task [for a review see: Kane, Conway, Miura \& Colflesh, 2007] (Figure 1). 

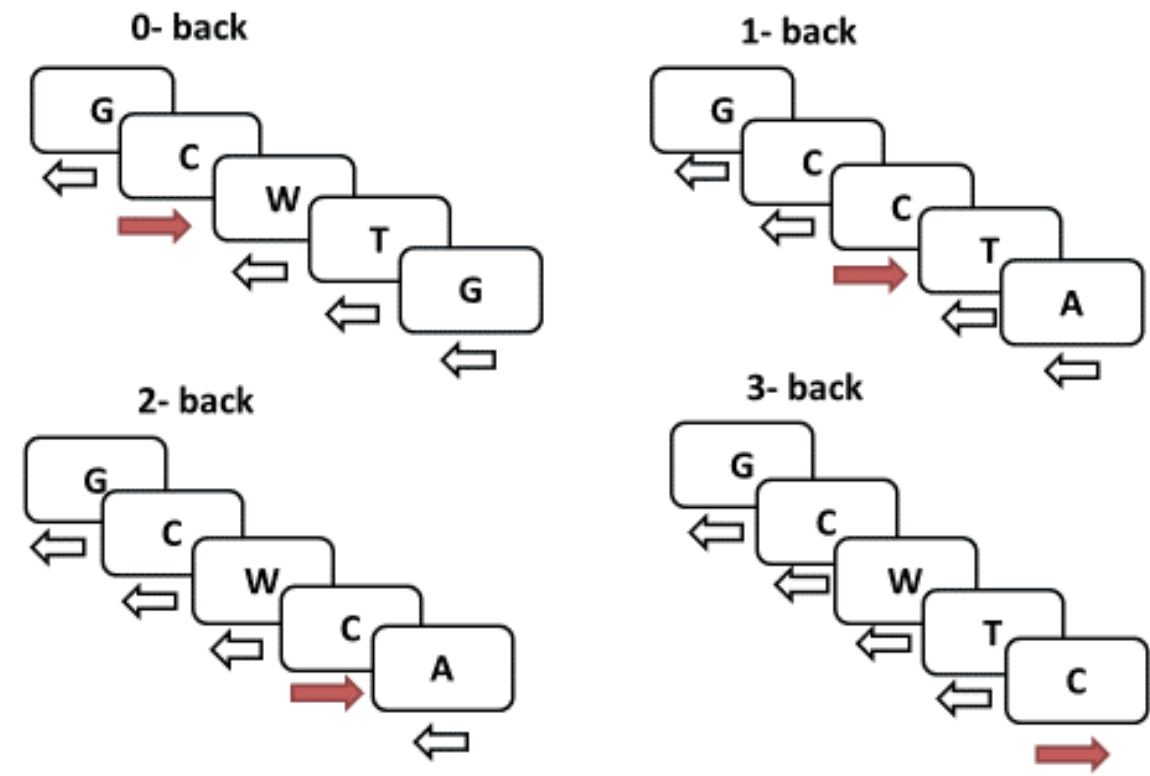

Figure 1. Exemplary N-back Task in four different variants

While the first variant (0-back) is a control condition, in the remaining variants $(1,2,3)$ the participant is asked to determine whether the current item occurred one, two or three items ago.

The n-back task requires subjects to react (by pressing a corresponding button) whenever each stimulus in a sequence equals the one that occurred $n$ items ago. Although n-back is considered a standard 'executive' working memory (WM) measure in cognitive neuroscience, it is also seen as a possible additional correlate of intelligence [Kane et al., 2007]. According to Spearman's two-factor theory of intelligence (1927), all human abilities can be described by two main factors: a general factor (referred to as fluid intelligence) and a specific factor (specific abilities). While the specific factor differs amongst individuals, fluid intelligence is defined as a "complex human ability" that allows us to adjust our thinking to new circumstances or cognitive problems for which we have not acquired proper knowledge yet [e.g. Carpenter, Just \& Shell, 1990]. Some experiments show a great overlap between Working Memory, Sensory Discriminatory Abilities, and Fluid Intelligence [Voelke, Troche, Rammsayer, Wagner, \& Roebers, 2013]. Moreover, Jaeggi et al. [2010] demonstrated that training on a dual n-back task results in improvements in fluid intelligence (Gf). Such improvement in fluid intelligence after training in an n-back task could indicate that working memory and fluid intelligence at least partially share substrates, and could be seen as parts of general intelligence. Fluid intelligence is considered critical for various cognitive tasks [Engle, Tuholski, Laughlin \& Conway, 1999; Gray \& Thompson, 2004] as measured by matrix reasoning tasks. Furthermore, fluid intelligence and working memory are assumed to be predictors of success when a cognitive situation is demanding. Recent studies have shown that Gf and WM span share 
much of the common variance, suggesting a mutual neural mechanism of those two. Burgess, Gonen-Yaacovi \& Volle [2011] measured n-back task performance while the participants underwent fMRI scans. The authors focused on the activation associated with high-interference lure trials. Lure trials are trials that match a recently presented stimulus but do not match the target stimulus. Those trials were used to examine interference that was caused by a strong familiarity signal and could have facilitated an incorrect response. When correlating the obtained brain activity in response to these trials with Gf, WM span and task performance, in the brain regions assumed to be responsible for working memory and executive control (i.e., bilateral dorsolateral prefrontal cortex - middle frontal gyrus and parietal cortex - inferior parietal cortex), it showed that interference control activity influences Gf through a set of various processes that also affect WM span.

To sum up, Working Memory, which is strongly associated with intelligence in adults [e.g. Conway et al., 2002; Engle et al., 1999; Voelke et al., 2013], might serve as a correlate of general intelligence.

\subsection{Working memory and cognitive functions in blind individuals}

It was shown that blindness can be linked with a relative enhancement of working memory as a compensatory mechanism. There are some factors that may be influencing participants' performance. It is possibly due to forming and organizing information using past visual experience [Chen, Huang \& Wang, 2010]. It was shown that both congenitally and late blind participants display comparable, high skills in tasks that require recalling information from memory, which can be considered as evidence of highly adaptive capabilities of the human brain [Röder \& Rösler, 2003]. The same mechanism was identified in other studies, providing supportive evidence for the hypothesis that the lack of vision leads to an enhancement of the attentional and working memory capacities [Pigeon \& Marin-Lamellet, 2014].

Bliss, Kujala, and Hämäläinen [2004] tested blind subjects with a tactile n-back task where the stimuli were either sets of raised letters or Braille characters, and compared their performance with that of sighted participants, who, instead of Braille characters, were presented with series of letters on a computer screen. As expected, the blind participants were significantly better in the tactile raised letters n-back task than the sighted ones. While the sighted participants made significantly fewer mistakes in the visual task than the blind subjects in the raised letters task, there was no difference between the visual performance by the sighted subjects and the tactile performance in the Braille task by the blind. Demonstrated research shows to what an extent everyday practice may contribute to the development of perceptual skills in both people without visual impairments and those with a severe sensory loss (e.g. blindness). The above-mentioned research also demonstrated that the level of performance in blind individuals and that of sighted people do not significantly differ, independently of the modality that they rely on (tactile vs. visual) [see also: Cohen, Scherzer, Viau, Voss \& Lepore, 2011]. 


\section{Summary}

In this paper, an attempt was made to describe current methods used to measure IQ in the blind. Even though current approaches in measuring intelligence in the blind population include a variety of tools, they do not seem to address all problems linked with transparency and validity. This is mainly due to the fact that such special populations are often rather heterogeneous and include individuals with diverse visual impairments. Intelligence tests help psychologists make recommendations about the kind of teaching that will benefit a child the most. According to GUS [Polish Central Statistical Office, 2004], around 1.8 million people are blind or partially sighted in Poland. In the year 2010, around 63 thousand people were associated in the Polish Association of the Blind (57\% women and $43 \%$ men) in all age groups (487 people aged $0-6 ; 6,496$ people aged 7-24; 29,946 people aged 25-64; 26,594 people aged over 65) [Kaczmarek, 2011]. It is therefore crucial to develop an appropriate IQ test that would assess the child's abilities. Moreover, finding a neural correlate of intelligence would not only allow researchers to develop an appropriate IQ test for the blind but would also shed additional light on cognitive functioning of this group and on ways to examine it. Here, we discussed current methods of evaluating intelligence in the blind. Despite their advantages, they have some limitations. Using a tactile version of an n-back task might be an interesting and additional tool to evaluate intelligence in this group. However, this approach is also not without some drawbacks. As mentioned above, even though the n-back task is a commonly used test to evaluate the working memory performance, it does not directly measure intelligence, although the correlation between the two was shown to be significant. Last but not least, because the blind population mostly relies on the sense of touch, it is unclear whether the performance of blind participants is truly linked with how well they do on a task, or rather with their highly sensitive and well-developed tactile abilities.

\section{BIBLIOGRAPHY}

Abu-Hamour, B., Al Hmouz, H., Mattar, J., \& Muhaidat, M. (2012). The use of Woodcock-Johnson tests for identifying students with special needs - a comprehensive literature review. Procedia - Social and Behavioral Sciences, 47: 665-673.

Acar, S., Hansen, S., Dolata, J., \& Chen, C.Y. (2014). An overview of developmental screening: Implications for practice. Bașent University Journal of Education, 1(1): 9-18.

Amedi, A., Malach, R., Hendler, T., Peled, S., \& Zohary, E. (2001). Visuo-haptic object-related activation in the ventral visual pathway. Nature Neuroscience, 4(3): 324.

Amedi, A., Raz, N., Pianka, P., Malach, R., \& Zohary, E. (2003). Early 'visual' cortex activation correlates with superior verbal memory performance in the blind. Nature Neuroscience, 6(7): $758-766$.

Anderson, R.P., \& Belz, H. (1964). Raven's Progressive Matrices for presentation to the blind: Final report. Lubbock, TX: Texas Technological College.

Ashcroft, S.C. (1959). Chapter VI: The blind and partially seeing. Review of Educational Research, 29(5): 519-528. 
Atkins, S. (2011). Assessing the Ability of Blind and Partially Sighted People: Are Psychometric Tests Fair? Birmingham: RNIB Centre for Accessible Information.

Bishop, V.E. (1996). Preschool Children with Visual Impairments. Texas School for the Blind and Visually Impaired.

Bliss, I., Kujala, T., \& Hämäläinen, H. (2004). Comparison of blind and sighted participants' performance in a letter recognition working memory task. Cognitive Brain Research, 18(3): 273-277.

Burton, H., Snyder, A.Z., Conturo, T.E., Akbudak, E., Ollinger, J.M., \& Raichle, M.E. (2002). Adaptive changes in early and late blind: a fMRI study of Braille reading. Journal of Neurophysiology, 87(1): 589-607.

Büchel, C., Price, C., Frackowiak, R.S., \& Friston, K. (1998). Different activation patterns in the visual cortex of late and congenitally blind subjects. Brain: A Journal of Neurology, 121(3): 409-419.

Bradley-Johnson, S. (1997). Brigance diagnostic life skills inventory. Psychology in the Schools, 34(4): 382-384.

Brand, H.J., Pieterse, M.J., \& Frost, M. (1986). Reliability and validity of the Ohwaki-Kohs tactile block design test for the blind. Psychological Reports, 58(2): 375-380.

Brigance, A.H. (1994). Brigance Diagnostic Life Skills Inventory. Curriculum Associates, Incorporated: Hawker Brownlow Education.

Burgess, P.W., Gonen-Yaacovi, G., \& Volle, E. (2011). Functional neuroimaging studies of prospective memory: what have we learnt so far? Neuropsychologia, 49(8): 2246-2257.

Canivez, G.L., Konold, T.R., Collins, J.M., \& Wilson, G. (2009). Construct validity of the Wechsler Abbreviated Scale of Intelligence and Wide Range Intelligence Test: Convergent and structural validity. School Psychology Quarterly, 24(4): 252.

Carpenter, P.A., Just, M.A., \& Shell, P. (1990). What one intelligence test measures: a theoretical account of the processing in the Raven Progressive Matrices Test. Psychological Review, 97(3): 404-431.

Cassar, C., \& Lucchese, F. (2016). Psychometric test for blind adults and children, critical issues and perspectives. International Journal of Developmental and Educational Psychology (Revista INFAD de Psicología), 2(1): 109-116.

Chen, M.S., Huang, Ch.K., \& Wang, Ch.N. (2010). Working memory for spatial construction in blind and sighted individuals. Journal of the Chinese Institute of Industrial Engineers, 27(3): 199-208.

Cohen, H., Scherzer, P., Viau, R., Voss, P., \& Lepore, F. (2011). Working memory for braille is shaped by experience. Communicative \& Integrative Biology, 4(2): 227-229.

Cohen, H., Voss, P., Lepore, F., \& Scherzer, P. (2010). The nature of working memory for braille. PLoS One, 5(5): 135-164.

Conway, A.R., Kane, M.J., \& Engle, R.W. (2003). Working memory capacity and its relation to general intelligence. Trends in Cognitive Sciences, 7(12): 547-552.

Dauterman, W.L. (1965). Stanford Ohwaki-Kohs Tactile Block Design Intelligence Test for Blind. Report Resume. Washington: U.S. Department of Health, Education and Welfare.

Davis, C.J. (1980). Perkins-Binet Tests of Intelligence for the Blind: Adapted Primarily from the Stanford-Binet Intelligence Scale, Third Revision, Form LM, with the Permission of Houghton Mifflin Company, Boston, Massachusetts. Perkins School for the Blind.

Dekker, R. (1993). Visually impaired children and haptic intelligence test scores: Intelligence Test for Visually Impaired Children (ITVIC). Developmental Medicine and Child Neurology, 35(6): 478-489.

Dial, J., Mezger, C., Gray, S., Massey, T., Chan, F., \& Hull, J. (1990). Manual: Comprehensive Vocational Evaluation System. Dallas, TX: McCarron-Dial Systems.

Duncan, E., Weidel, J.W., Prickett, H.T., Vernon, M., \& Hollingsworth-Hodges, T. (1989). The tactile TONI: A possible new performance IQ test for blind adults? Journal of Visual Impairment \& Blindness, 83(10): 510-511. 
Engle, R.W., Tuholski, S.W., Laughlin, J.E., \& Conway, A.R. (1999). Working memory, short-term memory, and general fluid intelligence: a latent-variable approach. Journal of Experimental Psychology: General, 128(3): 309.

Fewell R.R., \& Langley, M.B. (1989). Developmental Activities Screening Inventory-II. Austin, TX: Pro-ed Inc.

Główny Urząd Statystyczny (GUS) (2004). Stan zdrowia ludności Polski w 2004.

Gough, H.G., \& Domino, G. (1963). The D 48 test as a measure of general ability among grade school children. Journal of Consulting Psychology, 27(4): 344-349.

Gray, J.R., \& Thompson, P.M. (2004). Neurobiology of intelligence: science and ethics. Nature Reviews Neuroscience, 5(6): 471-482.

Harrison, P., \& Oakland, T. (2003). Adaptive Behavior Assessment System (ABAS-II). San Antonio, TX: The Psychological Corporation.

Hill-Briggs, F., Dial, J.G., Morere, D.A., \& Joyce, A. (2007). Neuropsychological assessment of persons with physical disability, visual impairment or blindness, and hearing impairment or deafness. Archives of Clinical Neuropsychology, 22(3): 389-404.

Hoover, H.D., Dunbar, S.B., \& Frisbie, D.A. (2003). ITBS Forms A and B Guide to Research and Development. Itasca: Riverside.

Hornowska, E. (2004). Skale Inteligencji dla Dorostych Davida Wechslera WAIS-R oraz WAIS-III. Warszawa: Wydawnictwo Naukowe Scholar.

Jaeggi, S.M., Studer-Luethi, B., Buschkuehl, M., Su, Y.F., Jonides, J., \& Perrig, W.J. (2010). The relationship between $n$-back performance and matrix reasoning - implications for training and transfer. Intelligence, 38(6): 625-635.

Kaczmarek, B.M. (ed.) (2011). Zbiorczy raport $z$ diagnozy świadczonych usług z zakresu rehabilitacji społecznej dla osób niepełnosprawnych w Polsce. Accessed August 4, 2018 from http:// www.koalicjaon.org.pl/photo/File/projekt_standardy/raport_zbiorczy_z_diagnozy_swiadczonych_uslug_rehabilitacyjnych.pdf.

Kane, M.J., Conway, A.R.A., Miura, T.K., \& Colflesh, J.H. (2007). Working memory, attention control, and the N-Back Task: a question of construct validity. Journal of Experimental Psychology, 33(3): 615-622.

Kucharczyk, I. (2015). Specyfika funkcjonowania poznawczego osób niewidomych. In: K. Czerwińska, M. Paplińska, M. Walkiewicz-Krutak (eds.). Tyflopedagogika wobec współczesnej przestrzeni edukacyjno-rehabilitacyjnej (pp. 77-87). Warszawa: APS.

Mason, H.L., \& Shukla, S.R. (1992). The use of the Blind Learning Aptitude Test in England and Wales, India and the USA. British Journal of Visual Impairment, 10(3): 95-99.

Mazella, A., Albaret, J.M., \& Picard, D. (2014). Haptic tests for use with children and adults with visual impairments: a literature review. Journal of Visual Impairment \& Blindness, 108(3): 227-237.

Mazella, A., Albaret, J.M., \& Picard, D. (2016). Haptic-2D: A new haptic test battery assessing the tactual abilities of sighted and visually impaired children and adolescents with two-dimensional raised materials. Research in Developmental Disabilities, 48: 103-123.

Miller, J.C., Skillman, G.D., Benedetto, J.M., Holtz, A.M., Nassif, C.L., \& Weber, A.D. (2007). A three-dimensional haptic matrix test of nonverbal reasoning. Journal of Visual Impairment \& Blindness, 101: 557-570.

Mohammed, Z., \& Omar, R. (2011). Comparison of reading performance between visually impaired and normally sighted students in Malaysia. British Journal of Visual Impairment, 29(3): 196-207.

Nelson, P.A., Dial, J.G., \& Joyce, A. (2002). Validation of the Cognitive Test for the Blind as an assessment on intellectual functioning. Rehabilitation Psychology, 47(2): 184-193.

Newland, T.E. (1969). The Blind Learning Aptitude Test. Washington: US Department of Health Education and Welfare. 
Newland, T.E. (1990). The Blind Learning Aptitude Test in rehabilitation assessment. Rehabilitation Psychology, 35(3): 181.

Nęcka, E., Orzechowski, J., \& Szymura, B. (2006). Psychologia poznawcza. Warszawa: Academica Wydawnictwo SWPS, Wydawnictwo Naukowe PWN.

Oberauer, K., Süß, H.M., Wilhelm, O., \& Wittmann, W.W. (2008). Which working memory functions predict intelligence? Intelligence, 36: 641-652.

Ohwaki, Y., Tanno, Y., Ohwaki, M., Hariu, T., Hasasake, K., \& Miyake, K. (1960). Construction of an intelligence test for the blind. Psychological Folia, 18: 45-65.

Paknikar, K. (1981). Vithoba Paknikar Performance Tests for the Blind. International Journal of Rehabilitation Research, 4: 223-224.

Pigeon, C., \& Marin-Lamellet, C. (2015). Evaluation of the attentional capacities and working memory of early and late blind persons. Acta Psychologica, 155: 1-7.

Postma, A., Zuidhoek, S., Noordzij, M.L., \& Kappers, A.M. (2007). Differences between earlyblind, late-blind, and blindfolded-sighted people in haptic spatial-configuration learning and resulting memory traces. Perception, 36(8): 1253-1265.

Reid, J.M.V. (2002). Testing the nonverbal intelligence of working-age visually impaired adults: Evaluation of the adapted Kohs Block Design Test. Journal of Visual Impairment and Blindness, 96: 585-595.

Reich, L., Szwed, M., Cohen, L., \& Amedi, A. (2011). A ventral visual stream reading center independent of visual experience. Current Biology, 21(5): 363-368.

Rich, C.C. (1963). The validity of an adaptation of Raven's progressive matrices test for use with blind children (Doctoral dissertation).

Rich, C.C., \& Anderson, R.P. (1965). A tactual form of the progressive matrices for use with blind children. Journal of Counseling \& Development, 43(9): 912-919.

Röder, B., \& Rösler, F. (2003). Memory for environmental sounds in sighted, congenitally blind and late blind adults: evidence for cross-modal compensation. International Journal of Psychophysiology, 50: 27-39.

Röder, B., Stock, O., Bien, S., Neville, H., \& Rösler, F. (2002). Speech processing activates visual cortex in congenitally blind humans. European Journal of Neuroscience, 16(5): 930-936.

Rust, J.O., \& Wallace, M.A. (2004). Book review: Adaptive behavior assessment system. Journal of Psychoeducational Assessment, 22(4): 367-373.

Sadato, N., Pascual-Leone, A., Grafman, J., Ibanez, V., Deiber, M.P., Dold, G., \& Hallett, M. (1996). Activation of the primary visual cortex by Braille reading in blind subjects. Nature, 380: 526-528.

Shukla, S.R. (1990). Applicability of the Blind Learning Aptitude Test to Indian children. International Journal of Rehabilitation Research, 13(2): 175-177.

Shurrager, H.C., \& Shurrager, P.S. (1964). HISab: Manual Haptic Intelligence Scale for Adult Blind. Chicago: Psychology Research Technology Center.

Spearman, C. (1927). The Abilities of Man. New York: Macmillan.

Spencer, R.A. (1996). Wechsler Intelligence Scale for Children - third edition verbal short forms for children with visual impairments (Doctoral dissertation). Retrieved from the University Libraries, University of Arizona.

Suinn, R., Dauterman, W., \& Shapiro, B. (1966). The Standard Ohwaki-Kohs Tactile Block Design Intelligence Test for the Blind. New Outlook for the Blind, 60: 77-79.

Teare, J.F., \& Thompson, R.W. (1982). Concurrent validity of the Perkins-Binet Tests of Intelligence for the Blind. Journal of Visual Impairment and Blindness, 76(7): 279-280.

Thiebaut, E., Collin, M., Bâton, C., \& Fourtier, A. (2002). Lépreuve B101-DV d'intelligence pratique de Bonnardel adaptée à un public d’aveugles et de malvoyants: Stabilité de la signification des mesures [Bonnardel's B101-DV test of practical intelligenceadapted to blind and visually impaired persons]. Psychologie et Psychométrie, 23: 7-33. 
Tobin, M.J., \& Hill, E.W. (2011). Issues in the educational, psychological assessment of visually impaired children: Test-retest reliability of the Williams Intelligence Test for Children with Defective Vision. British Journal of Visual Impairment, 29(3): 208-214.

Vander Kolk, C.J. (1982). A comparison of intelligence test score patterns between visually impaired subgroups and the sighted. Rehabilitation Psychology, 27(2): 115-120.

Voelke, A.E., Troche, S.J., Rammsayer, T.H., Wagner, F.L., \& Roebers, C.M. (2013). Sensory discrimination, working memory and intelligence in 9-year-old and 11-year-old children. Infant and Child Development, 22(5): 523-538.

Ward, M.E., \& Genshaft, J. (1983). The Perkins-Binet tests: A critique and recommendations for administration. Exceptional Children, 49(5): 450-452.

Wechsler, D. (1994). The Measurement of Adult Intelligence ( $3^{\text {rd }}$ ed.). Baltimore: Williams and Wilkins.

Wechsler, S.M., Nunes, C.S., Schelini, P.W., Pasian, S.R., Homsi, S.V., Moretti, L., \& Anache, A.A. (2010). Brazilian adaptation of the Woodcock-Johnson III Cognitive Tests. School Psychology International, 31: 409-421.

Wetzel, R., \& Knowlton, M. (2000). A comparison of print and braille reading rates on three reading tasks. Journal of Visual Impairment and Blindness, 94(3): 146-154.

Williams, M. (1956). Williams Intelligence Test for Children with Defective Vision. Windsor: National Foundation for Educational Research.

Withagen, A., Vervloed, M.P., Janssen, N.M., Knoors, H., \& Verhoeven, L. (2009). The Tactual Profile: Development of a procedure to assess the tactual functioning of children who are blind. British Journal of Visual Impairment, 27(3): 221-238. 